\title{
EVALUATION OF NEW LETTUCES CULTIVARS PRODUCED IN DIFFERENT CROP SYSTEMS
}

Claudia Margareth Abe Rossi ${ }^{1}$, Larissa Fontana ${ }^{1}$, Silviane Zanni Hubinger ${ }^{2}$, Carolina Medeiros Vicentini-Polette ${ }^{1}$, Marcos David Ferreira ${ }^{2}$, Marta Helena Fillet Spoto ${ }^{3}$, Fernando Cesar Sala ${ }^{4}$, Marta Regina Verruma-Bernardi ${ }^{4}$

${ }^{1}$ Graduate Program in Agroecology and Rural Development, Federal University of São Carlos (UFSCar), Campus Araras, E-mail: aberossi@ hotmail.com, lari-fontana@ hotmail.com, vicentini-polette@ outlook.com

${ }^{2}$ Brazilian Agricultural Research Corporation (Embrapa Instrumentation), E-mails: silviane.zanni@embrapa.br, marcos.david@embrapa.br

${ }^{3}$ University of São Paulo (USP), Luiz de Queiroz College of Agriculture (ESALQ), E-mail: martaspoto@usp.br

${ }^{4}$ Center of Agrarian Sciences, Federal University of São Carlos (UFSCar), E-mail: fcsala@ufscar.com, verruma@ufscar.br

\section{ABSTRACT}

Romanela and Rubinela lettuce cultivars are innovative varieties, since they are crunchy and tropicalized. This study aimed to verify characteristics and quality of these cultivars produced in conventional, hydroponic and organic systems. The lettuces were evaluated regarding leaf area, leaf size, unit leaf area, fresh mass, mass loss, turgidity pressure, instrumental color, $\mathrm{pH}$, total soluble solids, total acidity, total phenolic compounds, and sensory characterization. The cultivation systems influenced the physical characteristics size, weight and mass loss of Romanela lettuce, and fresh mass and mass loss for Rubinela lettuce. In the sensory evaluation, there were significant differences for green color, leaf size, crunchiness, grassy aroma and sweet taste for Romanela cultivar, the conventional and hydroponic being preferred. For Rubinela cultivar, there were differences for purple and green colors, leaf thickness and size, sweet and bitter tastes, the conventional and hydroponic being preferred, and the hydroponic presenting the highest purchase intention.

Keywords: Lactuca sativa, hydroponic, organic, physicochemical quality, sensory 


\section{AVALIAÇÃO DE NOVAS CULTIVARES DE ALFACES PRODUZIDAS EM DIFERENTES SISTEMAS DE CULTIVO}

\section{RESUMO}

As cultivares de alface Romanela e Rubinela são variedades inovadoras, por serem crocantes e tropicalizadas. Este estudo teve como objetivo verificar características e qualidade dessas cultivares produzidas nos sistemas convencional, hidropônico e orgânico. As alfaces foram avaliadas quanto à área foliar, tamanho da folha, área unitária da folha, massa fresca, perda de massa, pressão de turgidez, cor instrumental, $\mathrm{pH}$, sólidos solúveis totais, acidez total, compostos fenólicos totais e caracterização sensorial. Os sistemas de cultivo influenciaram as características físicas tamanho, peso e perda de massa de alface Romanela e perda de massa e massa fresca da alface Rubinela. Na avaliação sensorial, houve diferenças significativas quanto à cor verde, tamanho das folhas, crocância, aroma de grama e gosto doce da cultivar Romanela, sendo preferidas a convencional e a hidropônica. Para a cultivar Rubinela, houve diferenças nas cores roxa e verde, espessura e tamanho das folhas e gostos doce e amargo, sendo preferidas a convencional e a hidropônica, a hidropônica com maior intenção de compra.

Palavras-chave: Lactuca sativa, hidropônica, orgânica, qualidade físico-química, sensorial

\section{INTRODUCTION}

Lettuce (Lactuca sativa L.) is one of the vegetables with the highest consumption and economic importance worldwide, extensively cultivated in all continents, particularly in temperate and subtropical regions (MOU, 2008). In the United States of America, the leafy vegetable ranks as the $3^{\text {rd }}$ most consumed vegetable (USDA, 2015). Besides the culture, lettuce is low in fat and contains several polyunsaturated fatty acids, which is essential for health, such omega-6, linoleic acid, omega-3, and $\alpha$-linolenic acid (KAUR et al., 2014).

According to Ferreira et al. (2009), lettuce presents a wide adaptation to different climate conditions, the possibility of successive crops in the same year, a good preference and demand, becoming one of the most produced leafy vegetables in Brazil and preferred among the farmers that grow it in field or sheltered conditions.

Currently, there are different types of horticultural cultivation. Lettuce can be cultivated in the conventional, organic, open or sheltered field, and hydroponic (sheltered cultivation) systems, 
which present different characteristics in relation to their management practices, eventually influencing the quality parameters of this vegetable (SANTANA et al., 2006).

In the conventional production system, there is an intensive use of chemical inputs and genetic improvement directed to the physical productivity (ARBOS et al., 2010), leading to economic results that are visible in the short term such as the rise in productivity and agricultural efficiency (SOUZA, 2005).

The hydroponic cultivation represents an alternative to the conventional cultivation (PAULUS et al., 2012), in which the soil is substituted by an aqueous solution, containing only the minerals necessary for the vegetables (FURLANI, 1998). It presents advantages such as production in small areas, use of a low amount of water and fertilizers, reduction in the number of operators during the crop cycle, harvest anticipation, and reduction of pesticides. The disadvantages are the high initial investment and the need for specialized training (FAQUIN et al., 1996).

The organic agriculture emerges as a model for alternative cultivation involving the practice of plant production without the use of artificial compounds such as chemical fertilizers and soluble pesticides, veterinary drugs, hormones and antibiotics, and genetically modified organisms (LIMA \& VIANELLO, 2011; ARAÚJO et al., 2014). According to Brasil (2006) lettuce is one of the main vegetables produced in this system.

The segment of crispy lettuce has been an innovation for the Brazilian lettuce cultivation, being commercially released in the market in the end of 2010. Crispy lettuce does not form a head like the iceberg lettuce, it is considered a tropicalized cultivar and of slow bolting, advantageous characteristics for growth in the summer in different systems. Sala \& Costa (2012) described some changes that occurred in the Brazilian lettuce cultivation, and the most significant was the substitution of loose-leaf lettuce by Grand Rapids type. Another trend currently observed consists in the rise in the search for iceberg lettuce, whose consumption changed from $9 \%$ in 1995 to more than $34 \%$ in 2010.

Two new cultivars were developed: Romanela and Rubinela. The Romanela cv. is the first national cultivar that presents thicker leaves, leaf blade with a wavy margin and light green color, besides a sweetish taste, constituting a new option of lettuce cultivar of the Romaine type. Thus, Romanela is the first 3:1 cultivar of the market: it is crispy, curly and cos, making it a distinct cultivar from the others in the market. The Rubinela cv. is another new lettuce cultivar of the segment of lettuce that is crispy, tropicalized, resistant to downy mildew (Bremia lactucae), and 
tolerant to early bolting. It presents a bright red coloration, large size and thick leaves. It is the first crispy cultivar of red color (UFSCAR, 2013).

Considering that lettuce quality can be influenced by the production system and the recent release of Romanela and Rubinela cultivars in the market, this study is pioneer at evaluating the physical, physicochemical and sensory characteristics of these cultivars produced in the conventional, hydroponic and organic systems.

\section{MATERIAL AND METHODS}

Lettuce seedlings of the cultivars Romanela and Rubinela, from the Program for Genetic Improvement of UFSCar, were produced in disposable plastic trays of 200 cells each, filled with coconut fiber substrate. They were maintained in a sheltered environment for the production with irrigation by intermittent microaspersion for 30 days. The seedlings were transplanted in three cultivation systems.

\section{Systems of lettuce cultivation}

Lettuce conventional cultivation was performed in the Experimental Horticultural Area, located at the Center for Agricultural Sciences - CCA/UFSCar, Campus of Araras, São Paulo state, Brazil (22³0'84" S; 47³8'11"; $663 \mathrm{~m}$ of altitude). Soil chemical characterization in the depth 0 $20 \mathrm{~cm}$ was: organic matter $\left(39 \mathrm{~g} / \mathrm{cm}^{3)} ; \mathrm{pH}\right.$ in $\mathrm{H}_{2} \mathrm{O}(6.1)$; phosphorous resin $\left(137 \mathrm{mg} \cdot \mathrm{dm}^{-3}\right)$; potassium resin $\left(11 \mathrm{mmolc} . \mathrm{dm}^{-3}\right)$; calcium $\left(63 \mathrm{mmolc} . \mathrm{dm}^{-3}\right)$; magnesium $\left(15 \mathrm{mmolc} . \mathrm{dm}^{-3}\right)$; potential acidity $\left(25\right.$ mmolc. $\left.\mathrm{dm}^{-3}\right)$, sum of bases $\left(89 \mathrm{mmolc} \cdot \mathrm{dm}^{3}\right)$, cationic capacity (114 mmolc. $\left.\mathrm{dm}^{-3}\right)$, and base saturation index $\left(78 \mathrm{mmolc} . \mathrm{dm}^{-3}\right)$.

The flowerbeds were raised with a machine and the fertilization of plants, cover and other cultural traits were performed according to Filgueira (2008). The spacing adopted was $25 \mathrm{~cm}$ x 25 $\mathrm{cm}$ between plant and line, respectively.

The hydroponic cultivation was performed in the same area than the conventional one. The seedlings were maintained in a nursery for 10 days and, after this period, taken to the hydroponic profiles. The Nutrient Film Technique (NFT) system was employed with trapezoidal polypropylene (TP90) profiles with benches of 9\% drop for the passage of the nutrient solution with spacing of $25 \mathrm{~cm} \times 25 \mathrm{~cm}$ between plants and profiles. The nutrient solution used was the recommended by Furlani et al. (1998). The hydroponic system was installed under a 35\% red net. 
The organic cultivation was performed in the city of Cordeirópolis, São Paulo State, Brazil $\left(22^{\circ} 27^{\prime} 43.07 \mathrm{~S} 47^{\circ} 24^{\prime} 17.76^{\prime \prime} \mathrm{W}\right)$, on a commercial farm that grows organic products, using bovine manure and grass from the property to fertilize lettuce. The production was performed according to the local procedures, considering that the farm is commercial, and lettuces were received already harvested for analysis. The soil chemical characterization in the depth 0-20 cm was: organic matter $\left(42 \mathrm{~g} \mathrm{~cm}^{-3}\right)$; $\mathrm{pH}$ in $\mathrm{H}_{2} \mathrm{O}$ (6.6); phosphorous resin $\left(322 \mathrm{mg} \mathrm{dm}^{-3}\right)$; potassium resin $\left(18 \mathrm{mmolc} \mathrm{dm}^{-3}\right)$; calcium (75 mmolc $\left.\mathrm{dm}^{-3}\right)$; magnesium $\left(30 \mathrm{mmolc} \mathrm{dm}^{-3}\right)$; potential acidity $\left(25 \mathrm{mmolc} \mathrm{dm}^{-3}\right)$, sum of bases (123 mmolc $\left.\mathrm{dm}^{-3}\right)$, cationic capacity (148 mmolc $\left.\mathrm{dm}^{-3}\right)$, and base saturation index (83 mmolc $\left.\mathrm{dm}^{-3}\right)$.

\section{Physicochemical analyses of the lettuces}

Leaf area determination was performed immediately after the harvest of plants. Turgidity pressure, instrumental color, $\mathrm{pH}$, total soluble solids, total titrable acidity, and total phenolic compounds analysis were conducted.

In order to determine leaf area, a leaf area integrator Li-cor 3000A (Licor Inc., Lincoln, Nebraska, EUA) was employed, in triplicate for each cultivation system. The unit leaf area (ULA) was calculated according to Linhares et al. (2013).

The analysis of turgidity pressure was performed using the equipment Wiltmeter ${ }^{\circledR}$ and methodology according to Calbo et al. (2008), for nine days. In the period of the experiment, the samples were stored individually in an open polyethylene plastic bag, under controlled refrigeration in a chamber at $8^{\circ} \mathrm{C} \pm 1{ }^{\circ} \mathrm{C}$ and controlled relative humidity (RU) of 85 to $90 \%$. The results of loss of turgidity pressure were expressed in percentage.

Mass loss determination was performed with three lettuce plants from each system, for each cultivar studied. The plants were maintained with roots during the whole procedure. Each plant was weighed daily in a Micronal model B3600 semi analytical scale, with the precision of $0.01 \mathrm{~g}$. Mass loss was determined by the difference between the initial fresh mass and the final fresh mass of the sample, after 9 days, $\left(\mathrm{m}_{\mathrm{i}}-\mathrm{m}_{\mathrm{f}} / \mathrm{m}_{\mathrm{i}}\right)$, with the results expressed in percentage $(\%)$. Sample storage during the experiment occurred in a chamber with controlled refrigeration at $8{ }^{\circ} \mathrm{C} \pm 1{ }^{\circ} \mathrm{C}$ and relative humidity of 85 to $90 \%$.

Leaf instrumental color analysis was evaluated using the Reading system $\mathrm{L}^{*}, \mathrm{a}^{*}$ and $\mathrm{b}^{*}$ with the aid of a colorimeter Konika Minolta, model CR400s, (Konica Minolta Sensing Americas, 
Inc., New Jersey, EUA) calibrated in a white surface according to the International Commission on Illumination (CIE 1976 L, a*, b* - CIELAB) (MINOLTA, 1998). The read was performed in three leaves of the external area of two lettuce plants from each cultivation system.

For the physicochemical analyses, two lettuce plants from each cultivation system were separately grounded. The ground pulp was centrifuged (refrigerated centrifuge, Hettich model Rotina 380R) at $8000 \mathrm{rpm}$ at a temperature of $4{ }^{\circ} \mathrm{C}$ for fifteen minutes. The supernatant was separated and stored in a screw-capped tube at $8{ }^{\circ} \mathrm{C} \pm 1^{\circ} \mathrm{C}$. Physicochemical analyses of $\mathrm{pH}$, total soluble solids, total titrable acidity and content of total phenolic compounds were performed.

The $\mathrm{pH}$ was measured in a bench $\mathrm{pH}$ meter (Edutec, model EEQ9003-110) by the immersion of the electrode in the extract, in duplicate. The content of soluble solids was determined by a direct reading of the extract in a digital bench refractometer (Atago, model RX-5000 $\alpha$-Plus), with automatic temperature adjustment to $25^{\circ} \mathrm{C}$, and the results were expressed in ${ }^{\circ} \mathrm{Brix}$, in duplicate. The total titrable acidity was determined as the recommended by the Association of Official Analytical Chemists - AOAC, (1997), in duplicate, and the results were expressed in grams of organic acid per $100 \mathrm{~mL}$ of extract. The content of total phenolic compounds was determined according to the spectrophotometric method of Folin Ciocalteau (ROSSI JUNIOR \& SINGLETON, 1965) and the results were expressed in milligrams equivalents of gallic acid (EGA) in $100 \mathrm{~mL}$ of extract. The reads were performed in an ultraviolet-visible spectrophotometer (PerkinElmer, model Lambda 25), in triplicate.

\section{Sensory evaluation of the lettuces}

The lettuce heads were defoliated and the leaves were selected, washed, sanitized with a solution of $100 \mathrm{ppm}$ active chlorine for 15 minutes, centrifuged, stored in open plastic bags and maintained in a fridge at $8{ }^{\circ} \mathrm{C} \pm 1{ }^{\circ} \mathrm{C}$ until the application of the sensory tests, in the same day.

The ranking sensory test (ABNT, 1994) was performed in individual cabins under white light. A leaf of the Romanela cv. from each cultivation system was presented to 27 untrained assessors and a leaf of the Rubinela cv. from each cultivation system, to 22 untrained assessors. The samples were served on coded white plates. The assessors were asked to rank the samples in an ascending order for each attribute and according to the preference. The attributes evaluated for the Romanela cv. were: green color (light-dark), leaf softness (less-more), leaf size (lower-higher), leaf crunchiness (lower-higher), grassy aroma (strong-weak), sweet taste (less-more) and bitter 
taste (less-more). For the Rubinela cv., the attributes were: purple color (light-dark), green color (light-dark), leaf thickness (less-more), leaf size (lower-higher), leaf crunchiness (less-more), leaf softness (less-more), sweet taste (less-more) and bitter taste (less-more). The ranking of purchase intention was performed by the observation of the whole lettuce plants, using one plant of each treatment for each cultivar, presented to the same 27 and 22 untrained assessors for Romanela and Rubinela, respectively.

\section{Statistical analysis}

The physicochemical data were evaluated by the analysis of variance (ANOVA) and Tukey test to verify differences among the means $(p \geq 0.05)$ using the statistical software Minitab $^{\circledR} 17$ (Minitab 17 Statistical Software). The data from the ranking test was evaluated by the Friedman test (NEWELL \& MacFARLANE, 1987).

\section{RESULTS AND DISCUSSION}

\section{Physical analyses}

According to the results presented (Table 1), it was observed that the leaf areas of Romanela cv. lettuce cultivated in the three different systems did not differ statistically from each other $(\mathrm{p} \leq 0.05)$. Conversely, regarding leaf size and unit leaf area (ULA), there was a significant difference $(\mathrm{p} \leq 0.05)$ among the three systems, with the conventional system presenting the highest values for leaves and ULA, followed by the hydroponic system and the organic system.

Table 1. Physical parameters of the lettuces cv. Romanela and cv. Rubinela cultivated in conventional, hydroponic and organic production systems.

\begin{tabular}{llll|lll}
\hline \multirow{2}{*}{\multicolumn{1}{c}{ Parameters }} & \multicolumn{3}{c}{ Romanela Lettuce } & \multicolumn{3}{c}{ Rubinela Lettuce } \\
\cline { 2 - 7 } & ConvS & HydrS & OrgS & ConvS & HydrS & OrgS \\
\hline Leaf area (mm) & $125.04^{\mathrm{a}}$ & $97.21^{\mathrm{a}}$ & $83.30^{\mathrm{a}}$ & $154.30^{\mathrm{a}}$ & $171.70^{\mathrm{a}}$ & $168.70^{\mathrm{a}}$ \\
Leaf height (cm) & $24.40^{\mathrm{a}}$ & $22.10^{\mathrm{b}}$ & $18.80^{\mathrm{c}}$ & $17.80^{\mathrm{a}}$ & $18.10^{\mathrm{a}}$ & $16.40^{\mathrm{a}}$ \\
Leaf width (cm) & $23.80^{\mathrm{a}}$ & $16.40^{\mathrm{b}}$ & $13.00^{\mathrm{c}}$ & $19.50^{\mathrm{a}}$ & $20.80^{\mathrm{a}}$ & $18.00^{\mathrm{a}}$ \\
Unit leaf area (cm $\left.{ }^{2}\right)$ & $581.50^{\mathrm{a}}$ & $362.80^{\mathrm{b}}$ & $244.90^{\mathrm{c}}$ & $348.70^{\mathrm{a}}$ & $378.50^{\mathrm{a}}$ & $296.10^{\mathrm{a}}$ \\
Initial fresh mass (g/plant) & $413.30^{\mathrm{a}}$ & $320.30^{\mathrm{a}}$ & $137.70^{\mathrm{b}}$ & $105.90^{\mathrm{b}}$ & $162.40^{\mathrm{a}}$ & $46.61^{\mathrm{c}}$ \\
Final fresh mass (g/ plant) & $374.50^{\mathrm{a}}$ & $286.20^{\mathrm{b}}$ & $110.30^{\mathrm{c}}$ & $93.30^{\mathrm{b}}$ & $130.41^{\mathrm{a}}$ & $37.00^{\mathrm{c}}$ \\
Mass loss (\%) & $9.22^{\mathrm{b}}$ & $10.56^{\mathrm{b}}$ & $20.60^{\mathrm{a}}$ & $12.30^{\mathrm{b}}$ & $19.70^{\mathrm{a}}$ & $20.50^{\mathrm{a}}$ \\
Loss of turgidity pressure (\%) & $41.70^{\mathrm{a}}$ & $49.77^{\mathrm{a}}$ & $60.80^{\mathrm{a}}$ & $46.10^{\mathrm{a}}$ & $37.80^{\mathrm{a}}$ & $55.21^{\mathrm{a}}$ \\
\hline Values fllowed by
\end{tabular}

Values followed by the same letters, in the same line, did not differ from each other by the Tukey test ( $\mathrm{p} \geq 0.05)$. The values of mass loss and loss of turgidity pressure are relative to the end of the storage period ( 9 days). ConvS $=$ Conventional System; HydrS = Hydroponic System; OrgS = Organic System . 
The mass loss of the organic cultivation was significantly different from the other cultivation systems evaluated $(\mathrm{p} \leq 0.05)$ after nine days of storage of the lettuces, presenting a higher final mass loss than the lettuce samples from the conventional and hydroponic systems (Table 1). The progress of mass losses in the samples produced in the three cultivation systems were observed (Figure 1A). The organic lettuce reached values superior to $10 \%$ of mass loss in the sixth day of storage. In the hydroponic system, Romanela reached values superior to $10 \%$ of mass loss in the eighth day of storage. The conventional Romanela had not reached the $10 \%$ of mass loss in the end of the storage period.

The Rubinela lettuce $c v$. did not present significant differences ( $\mathrm{p} \geq 0.05$ ) for leaf area, leaf size and ULA among the different production systems studied (Table 1). Nevertheless, there was a significant difference between the systems in relation to the initial fresh mass $(\mathrm{p} \leq 0.05)$. The organic Rubinela cv. was $71.30 \%$ lower than the hydroponic cultivation and 56\% lower than the conventional cultivation. However, the conventional plant was $34.77 \%$ lower than the hydroponic plant.

The samples produced in the three cultivation systems presented a progressive water loss (Figure 1B), according to the rise in storage period. The conventional lettuce reached values superior to $10 \%$ of mass loss in the eighth day of storage. Nonetheless, the organic and hydroponic samples reached values higher than $10 \%$ of mass loss much earlier: for the organic lettuce, these values were reached in the third day of storage and between the third and fourth days for the hydroponic lettuce.
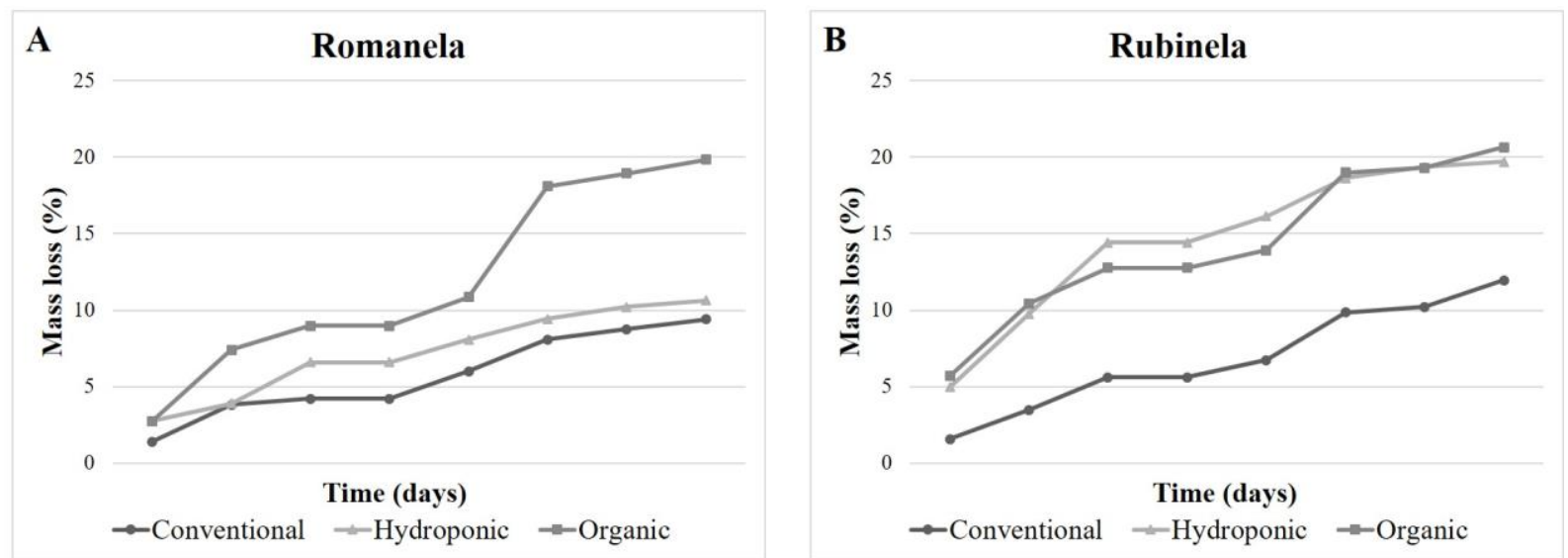

Figure 1. Analysis of the stability of Romanela (A) and Rubinela (B) lettuce during 9 days of storage. 


\section{Instrumental color and physicochemical analyses}

Presented in Table 2 are the results of the instrumental color analysis and physicochemical characteristics of the Romanela lettuce cv. in the cultivation systems studied.

Table 2. Instrumental color and physicochemical parameters of the Romanela and Rubinela lettuces $\mathrm{cv}$. in three cultivation systems.

\begin{tabular}{|c|c|c|c|c|c|c|}
\hline \multirow[t]{2}{*}{ Parameters } & \multicolumn{3}{|c|}{ Romanela Lettuce } & \multicolumn{3}{|c|}{ Rubinela Lettuce } \\
\hline & ConvS & HydrS & OrgS & ConvS & HydrS & OrgS \\
\hline L color & $61.60^{\mathrm{a}}$ & $58.60^{\mathrm{a}, \mathrm{b}}$ & $56.00^{\mathrm{b}}$ & $42.30^{\mathrm{a}}$ & $41.90^{\mathrm{a}}$ & $32.20^{\mathrm{a}}$ \\
\hline$a^{*}$ color & $-18.40^{\mathrm{b}}$ & $-19.60^{\mathrm{b}}$ & $-16.50^{\mathrm{a}}$ & $4.80^{\mathrm{b}}$ & $8.00^{\mathrm{a}, \mathrm{b}}$ & $11.50^{\mathrm{a}}$ \\
\hline$b^{*}$ color & $31.80^{\mathrm{a}}$ & $36.10^{\mathrm{a}}$ & $34.30^{\mathrm{a}}$ & $15.60^{\mathrm{a}}$ & $13.40^{\mathrm{a}, \mathrm{b}}$ & $6.60^{\mathrm{b}}$ \\
\hline $\mathrm{pH}$ & $5.81^{\mathrm{b}}$ & $5.90^{\mathrm{b}}$ & $6.10^{\mathrm{a}}$ & $6.00^{\mathrm{a}}$ & $5.80^{\mathrm{b}}$ & $5.90^{\mathrm{a}}$ \\
\hline TSS & $2.46^{\mathrm{b}}$ & $2.20^{\mathrm{c}}$ & $3.00^{\mathrm{a}}$ & $2.50^{\mathrm{b}}$ & $2.40^{\mathrm{b}}$ & $3.23^{\mathrm{a}}$ \\
\hline TTA & $1.53^{\mathrm{b}}$ & $1.90^{\mathrm{a}}$ & $1.60^{\mathrm{b}}$ & $1.30^{\mathrm{b}}$ & $1.95^{\mathrm{a}}$ & $1.30^{\mathrm{b}}$ \\
\hline TPC & $218.70^{\mathrm{c}}$ & $256.00^{\mathrm{b}}$ & $495.90^{\mathrm{a}}$ & $832.90^{\mathrm{c}}$ & $607.30^{\mathrm{b}}$ & $1191.70^{\mathrm{a}}$ \\
\hline
\end{tabular}

According to the results (Table 2), the content of total soluble solids (TSS) for Romanela cv. significantly differed among the studied systems. The value for the sample from the organic cultivation was $17.20 \%$ higher than the conventional cultivation and $27.30 \%$ higher than the hydroponic cultivation. Conversely, the conventional cultivation was $12.20 \%$ higher than the hydroponic cultivation.

The organic Rubinela lettuce presented the highest value for total soluble solids content statistically differing from the other two cultivations ( $\mathrm{p} \leq 0.05)$ (Table 2).

The Romanela cv. presented a significant difference among the three systems studied for total phenolic compounds (Table 2). The organic Romanela obtained a value 55.90\% higher than the conventional Romanela and $48.40 \%$ higher than the hydroponic Romanela. The hydroponic cultivation was $14.60 \%$ superior when compared to the conventional cultivation. The organic Rubinela presented values $30.10 \%$ higher than the conventional Rubinela and $49 \%$ than the hydroponic Rubinela. The conventional Rubinela was $27.10 \%$ superior to the hydroponic system.

\section{Sensory evaluation}

For the green color attribute, the organic Romanela presented the lightest coloration as, by the assessors responses, it obtained a ranking sum with the lowest value (Table 3). This sample was significantly different $(\mathrm{p} \leq 0.05)$ from the Romanela lettuces from the other cultivations, with 
the conventional Romanela presenting the highest value in the ranking sum indicating the darkest coloration, but it was not significantly different from the hydroponic lettuce.

It was verified that leaf size and crunchiness obtained the lowest ranking sum values in the organic Romanela lettuces, which means the smallest and least crunchy leaves, significantly differing from the conventional and hydroponic cultivations.

Regarding purchase intention, there was no significant difference among the Romanela lettuces $\mathrm{cv}$. from the three cultivation systems.

According to the assessors for the attributes purple color and green color, the conventional Rubinela cv. significantly differed from the hydroponic and organic samples. For the attribute purple color, the conventional Rubinela presented the most intense coloration, since it obtained the highest ranking sum value. Conversely, for the attribute green color, the conventional Rubinela presented the lightest coloration, obtaining the lowest sum value.

Table 3. Sum results for sensory attributes evaluated in the difference and preference ranking sensory test of Romanela and Rubinela lettuces.

\begin{tabular}{|c|c|c|c|c|c|c|}
\hline \multirow[b]{2}{*}{ Attributes } & \multicolumn{3}{|c|}{$\begin{array}{c}\text { Romanela Lettuce } \\
\text { (27 assessors) }\end{array}$} & \multicolumn{3}{|c|}{$\begin{array}{c}\text { Rubinela Lettuce } \\
\text { (22 assessors) }\end{array}$} \\
\hline & ConvS & HydrS & OrgS & ConvS & HydrS & OrgS \\
\hline Purple color & n.a. & n.a. & n.a. & $56^{\mathrm{a}}$ & $35^{\mathrm{b}}$ & $41^{b}$ \\
\hline Green color & $71^{\mathrm{a}}$ & $57^{\mathrm{a}}$ & $34^{\mathrm{b}}$ & $30^{\mathrm{b}}$ & $54^{\mathrm{a}}$ & $48^{\mathrm{a}}$ \\
\hline Leaf softness & $56^{\mathrm{a}}$ & $59^{\mathrm{a}}$ & $47^{\mathrm{a}}$ & $53^{\mathrm{a}}$ & $51^{\mathrm{a}}$ & $28^{\mathrm{b}}$ \\
\hline Leaf size & $72^{\mathrm{a}}$ & $61^{\mathrm{a}}$ & $29^{b}$ & $51^{\mathrm{a}}$ & $55^{\mathrm{a}}$ & $26^{\mathrm{b}}$ \\
\hline Leaf crunchiness & $62^{\mathrm{a}}$ & $62^{\mathrm{a}}$ & $38^{\mathrm{b}}$ & $45^{\mathrm{a}}$ & $49^{\mathrm{a}}$ & $37^{\mathrm{a}}$ \\
\hline Grassy aroma & $70^{\mathrm{a}}$ & $42^{b}$ & $50^{\mathrm{a}}$ & $48^{\mathrm{a}}$ & $41^{\mathrm{a}}$ & $53^{\mathrm{a}}$ \\
\hline Sweet taste & $36^{\mathrm{b}}$ & $57^{\mathrm{a}}$ & $69^{a}$ & $36^{\mathrm{b}}$ & $37^{b}$ & $59^{a}$ \\
\hline Bitter taste & $69^{\mathrm{a}}$ & $38^{b}$ & $55^{\mathrm{a}, \mathrm{b}}$ & $55^{\mathrm{a}}$ & $48^{\mathrm{a}}$ & $29^{b}$ \\
\hline Preference & $61^{\mathrm{a}}$ & $58^{\mathrm{a}}$ & $43^{b}$ & $45^{\mathrm{a}}$ & $59^{\mathrm{a}}$ & $29^{\mathrm{b}}$ \\
\hline Purchase intention & $57^{\mathrm{a}}$ & $59^{\mathrm{a}}$ & $47^{\mathrm{a}}$ & $40^{\mathrm{b}}$ & $56^{\mathrm{a}}$ & $24^{\mathrm{c}}$ \\
\hline
\end{tabular}

Sum values followed by different letters, in the same line, statistically differ by the Friedman test (minimal difference $=18)(\mathrm{p} \geq 0.05)$. ConvS = Conventional System; HydrS = Hydroponic System; OrgS = Organic System. n.a. $=$ not applicable.

For the attributes leaf thickness and leaf size of Rubinela cv., the organic sample significantly differed from the samples produced in the conventional and hydroponic systems. As stated by the assessors, the organic leaf was smaller and less thick than the leaves from the conventional and hydroponic cultivations.

The type of production system had influence on vegetable development. Regarding leaf height, leaf area, and unit leaf area, Romanela cv. in the conventional system stood out positively 
from the other systems ( $\mathrm{p} \leq 0.05$ ), although Rubinela did not present significant differences for these attributes. In addition, for leaf height, the lowest average found in Romanela $(18.80 \mathrm{~cm}$, organic system) was higher than the highest average found for Rubinela (18.10, hydroponic system), showing that Romanela leaves differ by their greater height, when compared to Rubinela. In the sensory evaluation, the organic lettuce leaf was considered the smallest for both cultivars.

Rubinela showed a significant difference $(p \leq 0.05)$ between all its treatments regarding the initial fress mass, while Romanela did not differ in any one. However, the highest average fresh mass obtained in Romanela was approximately $155 \%$ that the highest average obtained in Rubinela, corroborating the difference in size between the products.

Differently from the results found in this study, in which the conventional system (open field) presented the highest values for leaf size, ULA and initial fresh mass, Viana et al. (2013) obtained in a sheltered environment (greenhouse), higher values for leaf area and fresh mass when compared to the planting in open field. In a greenhouse, there is less incidence of solar energy because of the cover material (RADIN et al., 2004), and therefore higher values of these physical attributes were expected for the hydroponic cultivation, since it was performed in a sheltered environment.

When the harvested product loses 5 to $10 \%$ of its fresh weight, it starts to wilt and soon becomes unusable (MAHAJAN et al., 2008). For vegetables like lettuce, the cellular turgidity is directly related to quality, as leaf turgidity pressure is a variable of the state of water related to firmness, growth and with the consumers perception of wilting and freshness (CALBO et al., 2010).

The maintenance of leaf turgidity is favored when the roots are kept in the product, thus extending its commercialization period (SPRICIGO et al., 2009). In this study, the lettuces were stored whole, with roots, in open plastic bags and stored in a chamber of controlled refrigeration at $8{ }^{\circ} \mathrm{C} \pm 1{ }^{\circ} \mathrm{C}$ and controlled relative humidity (RH) of 85 to $90 \%$.

Silva et al. (2011), evaluating the quality of curly lettuce grown in different systems, found similar values for soluble solids in the lettuce produced in the conventional and organic systems, and both presented superior contents to those of the hydroponic lettuces. The soluble solids content is considered by some authors as an important attribute for the prediction of post-harvest lifespan of the lettuce. Thus, the higher this content in the freshly-harvested lettuce, the longer the period of its quality preservation (SILVA et al., 2011). 
In this study, organic lettuce, for both cultivars, had a significantly higher soluble solids content than the other systems $(\mathrm{p} \leq 0.05)$, a parameter related to the sugar content in the leaves and which was perceived by the assessors in the sensory test as sweet taste. Still, organic lettuces were the least preferred by the assessors.

Acidity (organic acids) determination can provide important information for the analysis of a food product state of conservation, since a decomposition process, by hydrolysis, oxidation or fermentation, usually alters the concentration of hydrogen ions (IAL, 2008). In this study, higher total acidity was detected in both cultivars when cultivated in the hydroponic system while there was no difference between the conventional and the organic, suggesting that the hydroponic system may improve the acidity of lettuce.

All treatments for the two lettuce cultivars presented $\mathrm{pH}$ values in the range considered ideal for vegetable tissues, that is, pH between 5.0 to 7.0 (MENEZES et al., 2005).

The phenolic compounds are substances widely distributed in nature and this big and complex group is part of the constituents of a variety of vegetables, fruits and industrialized products. They can be pigments, which give a colorful appearance to foods, or products from the secondary metabolism, usually derived from plant defense reactions against environmental aggressions (SILVA et al., 2010). They are important in vegetal foods due to their impact in flavor and color (particularly in the enzymatic darkening), potential health benefits, antioxidant activity and antimicrobial effects (BRECHT et al., 2008).

For total phenolic compounds, the results obtained in this study are superior to those found by Arbos et al. (2010), who compared lettuce Verônica cv. in the organic and conventional systems and obtained the values of $108.72 \mathrm{mg}$ EGA. $100 \mathrm{~g}^{-1}$ for the organic lettuce and $91.22 \mathrm{mg}$ EGA.100 $\mathrm{g}^{-1}$ for the conventional lettuce. These results for phenolic compounds are related to the more intense red color for the organic Rubinela and, in general, the organic system is a stressful system because of the lack of use of pesticides and synthetic fertilizers (CEGLIE et al., 2016).

The Romanela lettuce $\mathrm{cv}$. from the organic growth presented the lowest $\mathrm{L}^{*}$ value, that is, the darkest coloration and the conventional Romanela presented the highest value and, therefore, the lightest coloration. As expected, the Romanela lettuce presented negative values for the three systems studied indicating a green coloration. Nonetheless, the organic plant differed significantly from the other production systems $(\mathrm{p} \leq 0.05)$, presenting the highest $\mathrm{a}^{*}$ value and lowest $\mathrm{L}^{*}$ value, 
therefore, the darkest green color. The chromatic parameter $b^{*}$ was positive for the three systems studied, hence, yellowish leaves, and there was no statistical difference among them.

For the chromatic parameter $\mathrm{a}^{*}$, the conventional Rubinela presenting the lowest $\mathrm{a}^{*}$ value and the organic plant the highest, indicating that this is probably more reddish than the conventional sample. All $\mathrm{a}^{*}$ values obtained were positive, indicating the red coloration, which are coherent results for this cultivar, since Rubinela cv. presents an intense purplish color. The $\mathrm{b}^{*}$ parameter presented positive values, indicating a yellow coloration.

However, although these values are positive as those found for Romanela cv., the values for Rubinela cv. are inferior, since this cultivar has a purplish color. Lettuces have a coloration in several tones of green, varying from green-yellowish to dark-green, or a purple color (FILGUEIRA, 2008). Anthocyanin, present in a higher amount in the purple lettuce, acts as a natural antioxidant, which has beneficial effects for the health (LLORACH et al., 2008). In this study, the more intense red coloration in the organic Rubinela is correlated to the superior values of total phenolic compounds for this cultivation system (Table 2).

The sensory evaluation provides integral information regarding food quality, since the consumer chooses the food they are judging, somehow, if the product characteristics satisfy their expectations and demands (MELLO et al., 2003). For lettuces, the sensory evaluation can be an adequate tool in the evaluation of its quality and external appearance (BERNARDI et al., 2005).

The grassy aroma was more accentuated in the conventional and organic Romanela lettuces cv., as they had the highest sums in relation to the hydroponic lettuce. This attribute is related to the cultivation system, probably for being a controlled system, making use of a nutritious solution with enough mineral amounts for the plant and a lower amount of fertilizers.

According to the physical analyses and the attributes, there is an indication that the consumers prefer lettuce with highest leaf size, highest crunchiness and highest fresh mass characteristics.

The lower preference for organic lettuce may be linked to different factors, such as the higher concentration of total phenolic compounds when compared to other treatments. This parameter can affect the flavor of the vegetable and is particularly relevant in Rubinela, which, due to its anthocyanin content, had a content of up to $1191.7 \mathrm{mg} \mathrm{EGA} 100 \mathrm{~g}^{-1}$ (Table 2) and a preference of only 29 points - the lowest among the six samples evaluated (Table 3), although it was not perceived as the most intense purple color. 
Also, for Rubinela, this result can be related to the weight of the plants which were the highest in the samples from the conventional and hydroponic systems.

The taste and aroma of an agricultural product can be influenced by several factors such as the variability used, the type of soil and climate, the climatic year and the production system (organic and conventional) (DAROLT, 2003). Still according to this author, the studies of sensory quality which evaluate taste, aroma, acidity and palatability show a slight superiority of the organic product when compared to the conventional similar. In most of the comparative researches where the variables were well controlled there was a slight superiority of the organic product, however the results are statistically little significant (BOURN \& PRESCOTT, 2002).

\section{CONCLUSION}

This study provided the physical, chemical and sensorial characterization of Romanela and Rubinela lettuce cultivars grown in conventional, hydroponic and organic systems, demonstrating that the smallest lettuces, observed in organic treatments for both cultivars, tend to be the least preferred. In addition, the parameters evaluated in the new cultivars, Romanela and Rubinela, proved to be consistent with what was observed in the literature for other cultivars of the crisp type, thus suggesting the potential for production and consumption of these lettuces.

\section{ACKNOWLEDGMENTS}

This study was financed in part by the Coordination for the Improvement of Higher Education Personnel (CAPES) - CAPES (Brazil) - Finance Code 001.

\section{REFERENCES}

ABNT - ASSOCIAÇÃO BRASILEIRA DE NORMAS TÉCNICAS 1994. NBR 13170: Teste de ordenação em análise sensorial. Rio de Janeiro: ABNT, $7 \mathrm{p}$.

ARAÚJO, D.F.S.; SILVA, A.M.R.B.; LIMA, L.L.A.; VASCONCELOS, M.A.S.; ANDRADE, S.A.C.; SARUBBO, L.A. 2014. The concentration of minerals and physicochemical contaminants in conventional and organic vegetables. Food Control, v. 44, p. 242-248. https://doi.org/10.1016/j.foodcont.2014.04.005

ARBOS, K.A.; FREITAS, R.J.S.; STERTZ, S.C.; CARVALHO, L.A. 2010. Segurança alimentar de hortaliças orgânicas: aspectos sanitários e nutricionais. Ciência e Tecnologia de Alimentos, Campinas, v. 30, n. 1, p. 215-220.

AOAC - ASSOCIATION OF OFFICIAL ANALYTICAL CHEMISTS, 1997. Official methods of the association of official analytical chemists. 16. ed. Washington: 1298p. 
BERNARDI, A.C.C.; VERRUMA-BERNARDI, M.R.; WERNECK, C.G.; HAIM, P.G.; MONTE, M.B.M. 2005. Produção, aparência e teores de nitrogênio, fósforo e potássio em alface cultivada em substrato com zeólita. Horticultura Brasileira, Recife, v. 23, p. 920-924.

BOURN, D.; PRESCOTT, J. 2002. A comparison of the nutritional value, sensory qualities, and food safety of organically and conventionally produced food. Critical Reviews in Food Science and Nutrition, London, v.42, n.1, p. 1-34.

BRASIL - Ministério da Agricultura Pecuária e Abastecimento, 2006. Estatísticas: situação da produção orgânica 2006. Available at: < http://www.ibge.gov.br/home/estatistica/ economia/agropecuaria/censoagro/brasil_2006/Brasil_censoagro2006.pdf $>$ Accessed on: 10/12/2019.

BRECHT, J.K.; RITENOUR, M.A.; HAARD, N.F.; CHISM, G.W. 2008. Postharvest physiology of edible plant tissues. In: FENNEMA, O.R.; DAMODARAN, S.; PARKIN, K.L. (Eds). Fennema's Food Chemistry, New York: CRC Press, 4th ed. 1144p.

CALBO, A.G.; FERREIRA, M.D.; PESSOA, J.D.C. 2008. Wiltmeter ${ }^{\circledR}$ para a medida da firmeza das folhas. São Carlos/SP: Circular Técnica 43, Embrapa Instrumentação Agropecuária, $4 \mathrm{p}$.

CALBO, A.G.; FERREIRA, M. D.; PESSOA, J.D.C. 2010. A leaf lamina compression method for estimating turgor pressure. Hort Science, Alexandria, v. 45, n. 3, p. 418-423.

CEGLIE, F.G.; AMODIO, M.L.; COLELLI, G. 2016. Effect of organic production systems on quality and postharvest performance of horticultural produce. Horticulturae. Basel, v.2, n.4, p. 1-7.

DAROLT, M.R. 2003. Comparação da qualidade do alimento orgânico com o convencional. In: STRIGUETA, P.C. Alimentos orgânicos: produção, tecnologia e certificação. Viçosa: UFV, p. 289-312.

FAQUIN, V.; FURTINI NETO, A.E.; VILELA, L.A.A. 1996. Produção de alface em hidroponia. Lavras: UFLA, 50p.

FERREIRA, R.L.F.; ARAÚJO NETO, S.E.; ABUD, E.A.; REZENDE, M.I. F.L.; KUSDRA, J.F. 2009. Combinações entre cultivares, ambientes, preparo e cobertura do solo em características agronômicas de alface. Horticultura Brasileira, Recife, v. 27, n. 3, p. 383-388. http://dx.doi.org/10.1590/S0102-05362009000300023.

FILGUEIRA, F.A.R. 2008. Novo manual de olericultura: agrotecnologia moderna na produção e comercialização de hortaliças. 2. ed. Viçosa: UFV, 421p.

FURLANI, P.R. 1998. Instrução para o cultivo de hortaliça de folha pela técnica de hidroponia - NFT. Campinas: Instituto Agronômico, 30p.

IAL - INSTITUTO ADOLFO LUTZ. 2008. Métodos Físico-químicos para análise de alimentos. 4 ed. IAL: São Paulo.

KAUR, N.; CHUGH, V.; GUPTA, A.K. 2014. Essential fatty acids as functional components of foods-a review. Journal of Food Science and Technology, India, v.51, n.10, p.2289-2303.

LIMA, G.P.P.; VIANELLO, F. 2011. Review on the main differences between organic and conventional plant-based foods. International Journal of Food Science \& Technology, v.46, n.1, p.1-13. doi:10.1111/j.1365-2621.2010.02436.x.

LINHARES P.C.A.; SILVA, J.N.; FIGUEREDO, J.P.; SOUZA J.A.; SANTOS, J.G.R.; SOUZA, T.P.; MARACAJÁ, P.B. 2013. Crescimento da alface (Lactuca sativa), sob adubação orgânica em condições edafoclimáticas de Catolé do Rocha-PB. Revista Brasileira de Gestão Ambiental, Pombal, v.7, n.4, p.17-22.

LLORACH, R.; MARTÍNEZ-SÁNCHEZ, A.; TOMÁS-BARBERÁN, F.A.; GIL, M.I.; FERRERES, F. 2008. Characterisation of polyphenols and antioxidant properties of five 
lettuce varieties and escarole. Food Chemistry, v.108, n.3, p.1028-1038. http://dx.doi.org/10.1016/j.foodchem.2007.11.032.

MAHAJAN, P.V.; OLIVEIRA, F.A.R.; MACEDO, I. 2008. Effect of temperature and humidity on the transpiration rate of the whole mushrooms. Journal of Food Engineering, v.84, n.2, p. 281-288. https://doi.org/10.1016/j.jfoodeng.2007.05.021.

MELLO, J.C.; DIETRICH, R.; MEINERT, E.M.; TEIXEIRA, E.; AMANTE, E.R. 2003. Efeito do cultivo orgânico e convencional sobre a vida-de-prateleira de alface americana (Lactuca sativa L.) minimamente processada. Ciência e Tecnologia de Alimentos, Campinas, v. 23, n. 3, p. 418-426.

MENEZES, E.M.S.; FERNANDES, E.C.; SABAA-SRUR, A.U.O. 2005. Folhas de alface lisa (Lactuca sativa) minimamente processadas armazenadas em atmosfera modificada: análises física, químicas e físico-químicas. Ciência e Tecnologia de Alimentos, Campinas, v. 25, n. 1, p. 60-62.

MINOLTA, K. 1998. Comunicação precisa da cor: controle de qualidade da percepção à instrumentação. Minolta: Osaka, 59p.

MOU, B. 2008. Lettuce. In: NUEZ, F. (Ed). Vegetables I: Asteraceae, Brassicaceae Chenopodicaceae and Cucurbitaceae. Springer: New York, p. 75-116.

NEWELL, G.J.; MacFARLANE, J.D. 1987. Expanded tables for multiple comparison procedures in the analysis of ranked data. Journal of Food Science, v.52, n 6, p. 1721-1725. doi: 10.1111/1750-3841.15135.

PAULUS, D.; DOURADO NETO, D.D.; PAULUS, E. 2012. Análise sensorial, teores de nitrato e de nutrientes de alface cultivada em hidroponia sob águas salinas. Horticultura Brasileira, Recife, v. 30, n. 1, p. 18-25.

RADIN, B.; REISSER JÚNIOR, C.; MATZENAUER, R.; BERGAMASCHI, H. 2004. Crescimento de cultivares de alface conduzidas em estufa e a campo. Horticultura Brasileira, Recife, v. 22, n.2, p.178-181.

ROSSI JUNIOR, J.A.B.; SINGLETON, V.L. 1965. Colorimetry of total phenolics with phosphomolybdic phosphotungstic acid reagents. American Journal of Enology and Viticulture, Davis, v. 16, n. 3, p. 144-158.

SALA, F.C.; COSTA, C.P. 2012. Retrospectiva e tendência da alfacicultura brasileira. Horticultura Brasileira, Recife, v. 30, n. 2, p. 187-194. http://dx.doi.org/10.1590/S010205362012000200002.

SANTANA, L.R.; CARVALHO, R.D.S.; LEITE, C.C.; ALCÂNTARA, L.M.; OLIVEIRA, T.W.S.; RODRIGUES, B.D.A.M. 2006. Qualidade física, microbiológica e parasitológica de alfaces (Lactuca sativa) de diferentes sistemas de cultivo. Ciência e Tecnologia de Alimentos. Campinas, v. 26, n. 2, p. 264-269.

SILVA, E.M.N.C.P.; FERREIRA, R.L.F.; ARAÚJO NETO, S.E.; TAVELLA, L.B.; SOLINO, A. J.S. 2011. Qualidade de alface crespa cultivada em sistema orgânico, convencional e hidropônico. Horticultura Brasileira, Recife, v. 29, n. 2, p. 242-245. http://dx.doi.org/10.1590/S0102-05362011000200019.

SILVA, M.L.C.; COSTA, R.S.; SANTANA, A.S.; KOBLITZ, M.G.B. 2010. Compostos fenólicos, carotenoides e atividade antioxidante em produtos vegetais. Semina: Ciências Agrárias, Londrina, v. 31, n. 3, p. 669-682.

SOUZA, N.J. 2005. Desenvolvimento econômico. 5. ed. Atlas: São Paulo.

SPRICIGO, P.C.; BERTINI, V.A.; FERREIRA, M.D.; CALBO, A.G.; TAVARES, M. 2009. Avaliação pós-colheita de alface hidropônica, em função da quantidade de raízes, utilizando o equipamento Wiltmeter®. Horticultura Brasileira, Brasília, v. 27, p. S3790-6. 
UFSCAR - Universidade Federal de São Carlos - Agência de Inovação, 2013. Alface Romanela. Available at: <http://www.inovacao.ufscar.br/carteira-de-pi/335-alface-romanela $>$ Accessed on: Abr. 6, 2020.

USDA - United States Department of Agriculture, 2015. National nutrient database for standard reference. 28. ed. USDA: Washington.

VIANA, A.P.T.; DANTA, R.T.; SILVA, R.T.S.; COSTA. J.H.S.; SOARES, L.A.A. 2013. Cultivo de alface sob diferentes condições ambientais. Agropecuária Científica no Semiárido, Campina Grande, v. 9, n. 2, p. 21-26. 